\title{
Intersections between Race and Class: \\ A Postcolonial Analysis and Implications for Organizational Leaders
}

Eloisio Moulin de Souza ${ }^{1}$

Universidade Federal do Espírito Santo, Vitória, ES, Brazil ${ }^{1}$

Received 24 May 2018. This paper was with the author for three revisions. Accepted 3 April 2019. First published online 15 April 2019.

Anete Alberton was the associate editor for this article.

Editorial assistant: Luciane Kato Kiwara

Editor-in-chief: Carlo Gabriel Porto Bellini 


\begin{abstract}
This article seeks to understand the construction of racial identity in the Brazilian social context and its intersections with social class, aiming to analyze the occurrence of race resignification in this intersectional process, a process called the classification of race herein. Considering that business students will be leaders involved with the elaboration of organizational policies, this article seeks to contribute to the development of racial diversity policies in the field. Interviews were thus held with undergraduate students of management in a Brazilian university. The interviews occurred in focus groups, and data analysis was performed by means of discourse analysis from a postcolonial identity perspective, which allowed us to conclude that the boundaries between race and class are quite tenuous, to the point that racial aspects are reduced to merely involving social class. At the same time, social class acts as a form of whitening. The reduction of race to social class is a strategy of denying race as a social marker that produces inequalities and denying the existence of structural racism in the Brazilian society, thus bearing the myth that Brazil is a racial democracy.
\end{abstract}

Key words: race; class; intersectionality; identity; structural inequalities. 


\section{Introduction}

Considering that races are historical discursive productions with specific intelligibilities produced as a function of time and space (Hall, 2000), this article aims to analyze the intelligibility that undergraduate students of management have regarding race in the Brazilian context, focusing on the possible intersections between race and social class. Therefore, the main focus of this article is the study of racial identities and how they can be resignified by other forms of identity, specifically social class. The main assumption is that the meaning of race does not exist a priori and in isolation, rather being an interdependent construction with social class, referred to in this article as classification of race, a construction that resignifies race beyond phenotypic characteristics and produces structural inequalities that deconstruct the myth that Brazil is a racial democracy. For example, in terms of income equality between whites and blacks in Brazil, the report of the Oxford Committee for Famine Relief (OXFAM) asserts that whites earn on average per month $(\mathrm{R} \$ 1,589.00)$ twice as much as blacks earn $(\mathrm{R} \$ 898.00)$. The report also adds that in the last twenty years black incomes, which accounted for $45 \%$ of whites' income, rose to 57\% (OXFAM, 2017).

Despite management and business schools being located within the social sciences, several authors argue that there is still a silence in organizational studies on race relations (Cox \& Nkomo, 1990; Ely \& Meyerson, 2000; Harding, Ford, \& Fotaki, 2013; Holvino, 2010; Konrad, 2003; Zanoni, Janssens, Benschop, \& Nkomo, 2010). Generally, such silence is justified by the fact that race is not considered as an organizational phenomenon and an organizing principle (P. Prasad, Pringle, \& Konrad, 2006). Race is something evident and visible, but it is also a segregated, denied and avoided aspect in organizations (Acker, 2006). This paper seeks to understand how race identity is intersected by class, thus contributing to studies on intersectionality and adding to the few organizational works that analyze the intersectionality between race and class (Acker, 1999; Calás \& Smircich, 1996; Harding et al., 2013; Holvino, 1994, 1996, 2010; Munro, 2001).

In this sense, this article aims to contribute to the debate within the scope of organizational studies as explained next. First, universities and management/business schools are organizations, and the study of postcolonial and racial aspects presented in these types of organizations by organizational researchers only recently began to be scrutinized at a global level (Manning, 2018; Marjo, Juusola, \& Kivijärvi, 2019). About this, Marjo, Juusola and Kivijärvi (2019), when analyzing neocolonial relations in international business school campuses in United Arab Emirates, emphasize that the business schools have an important role in the education and formation of the identity of students, as well as in the development of the sense of community. Also, in a postcolonial approach, Manning (2018) asserts that business and management schools are often focused on developing knowledge and ignoring the empirical process through which knowledge is produced in everyday interactions, and that modernity, capitalism and coloniality are interconnected aspects which act to control knowledge and subjectivity. This paper then seeks to contribute to and advance the debate in two main aspects. First, by analyzing how management students' knowledge of race is shaped and signified by class, allowing the diagnosis of the political strategic intentionality of the classification of race in 
the formation of race identity, problematizing the knowledge produced in everyday interactions that are (re)produced in management school spaces, and considering that in most countries of the world the business courses discuss diversity. For example, in Brazil, the Ministry of Education has made mandatory to teach issues on race in administration courses. The diagnosis also highlights which misunderstandings and strategic political processes about race must be clarified and addressed during the training of business students and their formation as leaders. Then, studying the Brazilian reality permits at the same time to understand and analyze the political effects produced by colonialism in both colonizer and colonized countries. And second, the article contributes with intersectional and postcolonial identity approaches by establishing the connections between them related to the studies on identities, thus also enabling the deconstruction of knowledge produced in everyday interactions that race is not a racial marker (a concept that was established by the signification of racial identity inequalities as meaning merely social class inequalities). This breaks with the myth that there is no structural racism. Within the field of intersectionality in organizational studies, the postcolonial approach allows for the emergence of new theories, concepts and knowledge previously undervalued by colonizers, giving voice to organizational studies carried out outside the Anglo-Saxon axis. Postcolonialism has a very contentious meaning, there being diverse, different and even antagonistic definitions. In this article, a postcolonial approach of identity means that the study of cultural codes and shared historical experiences emerged in power relations that shape racial identities and knowledge, problematizing how race identity is represented in dominant colonial discourses that circulate in societies that were in their past European colonies (Hall, 1990, 1996). In this sense, intersectionality has been developed to signify and deconstruct the continuous and complex entanglement of processes of difference, exclusion and inclusion among identities (Acker, 2011), and several studies on intersectionality have been developed to explore the contingencies and complexities between identities in the production of multiple inequalities and markers of social differences (Harding et al., 2013). Because it does not reduce subjects exclusively to a single essential identity category and understands that social positions are relational, intersectionality has become a rich and complex approach to identity (Phoenix \& Pattynama, 2006).

Intersectional theory has emerged in black feminist studies, which explains why most intersectional studies have studied the intersections between gender and race. In this sense, this article also intends to advance the field of intersectional studies by analyzing the intersections between race and social class, which is why the intersections related to gender will not be addressed in this article. Then, this paper seeks to understand the relational positioning between race and class identities and, in doing so, deconstruct the idea that Brazil is a racial democracy, mainly deconstructing the idea that race identity is reduced to merely class issues in an attempt to mask the existence of structural racism in Brazil. Although there are intersections between race and class, they are two different identities, and the meaning and importance of race identity is not subordinate to and determined by class. The classification of race is a power strategy that aims to hide the importance of racial identities as a social marker in an attempt to mask and perpetuate racial inequalities. Thus, the intersections between race and class highlight two dimensions of analysis: (a) how the intersection between race and class resignifies race 
beyond phenotypical characteristics, and (b) the political goal and strategy of this process of race resignification by class.

The article is organized as follows. The main concepts used to understand how identities are understood are presented, emphasizing the fluid, intersectional and non-essential character that surrounds the processes of identity construction. Later, the meaning of race is discussed from a postcolonial perspective, seeking to understand the concepts of race, racialization and racism. Next, the racial specificities in the Brazilian historical, cultural and social context are discussed, especially focusing on its particularities. In sequence, the methodology used in the empirical research is described, and analyses of the produced data are performed. Finally, the main conclusions of the article are presented.

\section{Identities: Political Categories Discursively Constituted}

Identities are social organizations (Baines, 2010) that produce the normal and the abnormal in society. Identity is a set of interactions materially and symbolically contingent on language and representation (Braidotti, 1997), constituting itself as a political category that establishes power relations (Jones \& Stablein, 2006). Therefore, identities are processes of identification compelled by the desire to belong to categories (Moore, 1994), which makes them an affirmation of differences produced through discourse rather than a voluntary act of the subject (Bhabha, 1994; Braidotti, 1997; Butler, 1993, 1997; Foucault, 1970, 1982; Hall, 1996). The subject is constituted by multiple practices of categorization and regulation (Cohen, 1997) that consistently produce fluid, heterogeneous, political and antagonistic identities (Lovaas \& Jenkins, 2007), where language acts normatively by framing boundaries and existential possibilities (Seidman, 1994). Therefore, although identities are at the personal level, identities are not individual, but cultural, historical, social and collective (Ainsworth \& Hardy, 2004).

The term intersectionality was coined by Crenshaw (1989) to address the links and relations between gender, race, class and other identity categories (A. Prasad, 2012). "Intersectionality is thus useful as a handy catchall phrase that aims to make visible the multiple positioning that constitutes everyday life and the power relations that are central to it" (Phoenix \& Pattynama, 2006, p. 187). Therefore, intersectionality is the continuous and complex process of interlocking processes that produce difference, exclusion, inclusion, and discrimination (Acker, 2011), whereby identities, such as race and class, form an interdependent system and are experienced and constituted of form simultaneously and united rather than separate and additive, producing oppressions and hierarchies (Acker, 1999, 2011; Collins, 1995).

Intersectionality is a rich approach and a more complex ontology than approaches that usually study identities by reducing subjects to only one category (Phoenix \& Pattynama, 2006). In this way, social positions are relational, and intersectionality makes visible the interweaving between the multiple social positions and the relations of power that constitute the subject (Phoenix \& Pattynama, 2006), showing the multiple disadvantages experienced by the individuals positioned at the intersections of several difference markers without considering that the subjects' identity would simply be the sum of these several markers (Harding et al., 2013). 
Power, inequities and identities are interconnected and act together to form one another, making identities hybrid, fluid, heterogeneous, political, and multiple (Harding et al., 2013; Holvino, 2010). Current class and racial relations are a displacement of the division of labor produced by nineteenth-century colonialism, where class mobility of colonized racial subjects is somewhat lethargic (Spivak, 1988). In this sense, Foucault's work deals with real history, politics and social problems, and the conceptual apparatus of his work is pertinent to explain colonial phenomenon of the subjective sovereignty (Spivak, 1988). Influenced by Foucault in his postcolonial approach, Hall (1996, p. 444) states that the "end of the essential black subject also entails recognition that central issues of race always appear historically in articulation and in a formation with other categories and divisions and are constantly crossed and recrossed by the categories of class, gender and ethnicity". As Alcoff (1991, p. 8) says, "Groups identities and boundaries are ambiguous and permeable, and decisions about demarcating identity are always partly arbitrary and the process of positioning in the discourse is always complex". The process of decolonization can only occur by paying attention to social identities (Alcoff, 1991).

Thus, intersections of race, class, sexuality and gender are simultaneous processes of identity construction (Holvino, 2010) and not merely additive processes of oppression (Harding et al., 2013). As previously stated, considering oppressions as purely additive is somewhat simplistic and essentialist precisely because it involves an implicit hierarchy of disadvantages (Valentine, 2007). In this sense, race and class form an interdependent system and are experienced and constituted simultaneously, rather than separately and additively, producing oppressions and hierarchies (Acker, 1999, 2011; Collins, 1995). An intersectional perspective seeks to break with the stability, the pre-discursive existence and the essentialization of identity categories so present in an additive perspective, evidencing the fluidity between these categories (Bredström, 2006; Phoenix \& Pattynama, 2006; Yuval-Davis, 2006), because identities mutually construct each other. However, despite mutual constitution, different forms of identities cannot be seen as similar and equally structured (Phoenix \& Pattynama, 2006; Verloo, 2006; Yuval-Davis, 2006). In this sense, intersectionality does not conceive identities as essential properties of subjects but rather exploits the always mobile intersections of race, gender, class, sexualities and their specific arrangements (Holvino, 2010) that produce multiplicities.

Identity entails discursive practices by which people are led to position themselves according to the positions of others within discourses in a specific space and time (Linstead \& Pullen, 2006). "Identities are, so to speak, the positions by which the subject is obliged to occupy [...]" in the discourse (Hall, 2000, p. 19), constituting themselves as "social products, results of the identification work in which speakers engage when they interact" (Tate, 2005, p. 21). Any representation becomes possible "only because enunciation is always produced within codes which have a history, a position within the discursive formations of a particular space and time" (Hall, 1996, p. 446). Discourse is constitutive and not merely representative of a culture; therefore, it is formative and not merely expresses subjectivities, identities and policies (Hall, 1996). Understanding reality through this perspective implies denaturalizing what appears to be natural (Ainsworth \& Hardy, 2004). In this sense, it is the arrangements produced in different historical contexts that produce specific identities and their intelligibilities (Butler, 1990; Foucault, 1970, 1982; Hall, 2000). 
The essential conception of identities aims at keeping intact and preserving the privileged identities (white, heterosexual, and masculine) to the detriment of other identities that will be relegated (black, homosexual, and feminine) (A. Prasad, 2012). Identities considered nonessential are seen as a contingent process, always under construction and deconstruction, a constant and continuous becoming, always constructed as something to become that never ends, always multifaceted and fragmented by discourses (Tracy \& Scott, 2006). Identities are fragmented and fractured, never individual, but always political multiplicity built through difference. There are several forms of identities (gender, sexuality, race, class, among others), and considering that the object of this paper is racial identity, the next session of the article discusses what race identity is.

\section{Race Identities}

Race is a concept that brings us back to social relations and thus presents itself as a useful concept for the analysis and description of social relations (Schwarcz, 2001), because race is an identity based upon which human beings are differentiated, classified and hierarchized (Gilroy, 2001). In this sense, the concept of race ceases to be thought of as meaning blood, and contemporarily it is seen as a cultural and historical phenomenon. In other words, what at first appears and presents itself as materially natural and biological must be understood as a discursive construction (Anzaldúa, 1987). Races are relationships, practices, and systems of meaning that permeate and structure any society, producing hierarchies and inequalities (Acker, 2011). "Race' refers to socially defined differences based on physical characteristics, culture, and historical domination and oppression, justified by entrenched beliefs" (Acker, 2006, p. 444). The genotypic or phenotypic essentialization of race naturalizes and becomes ahistorical differences, disguising and masking what is historical and cultural as being natural, biological and genetic (Hall, 1993).

In this sense, races are social and cultural differences, generally justified, covert, grounded and marked by physical differences, such as skin color and hair type, but which are in fact rooted and constructed by diverse social, cultural, economic and ideological practices (Acker, 2011; Appiah, 1985). Race is not a natural property belonging to certain types of bodies but rather a discursive, social and historical construction on bodies surrounded by power relations. Race not only has a social meaning but also carries with it an ontological truth that acts as an organizing principle of the social (DuBois, 1970); that is, race is a changing and fluid identity aspect constructed through social, ideological and cultural interactions (Baines, 2010; Sansone, 1996; Swan, 2010). Therefore, races are groups historically and culturally defined with the purpose of producing identities with a strategic intentionality (Letiche, 2009).

Racialization is the name given to this historical and cultural process of social construction of races. The concept of racialization breaks with the established and legitimized patterns that conceive race as being a simple characteristic determined by the biology of bodies, breaking with the rational view that essentializes the concept of race (Gilroy, 2001). Therefore, the concept of racialization declares that race is not determined by biology (Gilroy, 2001), although 
it relies on biology to justify the power relations established through this process to camouflage its political content. This process of racialization, named by Omi and Winant (1986, p. 61) as racial formation, can be defined as the "process by which social, economic, and political forces determine the content and importance of racial categories, and by which they are in turn shaped by racial meanings". Through racialization, the borders are naturalized by hegemonic political projects that aim to exclude and marginalize certain types of subjects (Yuval-Davis, 2006).

The categorization of people into racial categories, and the creation of differences and hierarchies between these categories, is the main product of racialization processes (Murji \& Solomos, 2005). Racialization is also a product of capital demand for labor, in which certain races become inferior to justify their exploitation. In this sense, "racialization has been the place of a contradiction between the promise of political emancipation and the conditions of economic exploitation", which is made by considering certain populations as deviant or backward (Ferguson, 2003, p. 15). In addition, the processes of racialization make natural the idea that certain types of bodies are more adequate than others for certain works (Acker, 2011).

The production of race to distinguish different groups leads to racism, which is the "imposition of political, social, and economic power, as justified by racial categorizations" (Walton \& Caliendo, 2011, p. 6), which has as strategy constituting and subordinating a particular race to have control over it. Racism demands and assumes that racial identities are unitary and monolithic (Barnard, 1999). Racism can be analyzed both individually and structurally. When racism is analyzed in terms of individual attitudes and behaviors of aversion to a particular race category, it is denominated individual racism and considers only the micro-level of analysis (Henry \& Tator, 2005; Pierce, 2014). Structural racism, in contrast, is a system of power that produces disadvantages for certain races to the benefit of others, whereby racism is understood and explained through social structures and institutions situated in the macrosocial level rather than individual attitudes (Pierce, 2014). In this sense, structural racism "must be understood in terms of injustice rather than disrespect" (Pierce, 2014, p. 23). Whereas the individualistic approach favors the study of moral, psychological or ethical aspects, the structuralist approach favors socio-political and economic analysis (Pierce, 2014). Specifically in Brazil, one of the main strategies of racialization is to deny the relation between social inequality and race (Silveira \& Nardi, 2014) in order to deny the existence of structural racism in the Brazilian society. In this context, racism is conceived as an individual act rather than a structural aspect (M. N. da Silva, 2000).

Since this article addresses racial issues in the Brazilian context, it is necessary to understand some specific characteristics about the racialization process in Brazil.

\section{Race and class in Brazil: the myth of racial democracy}

For Guillaumin (1995), racism emerged in the history of the West between the eighteenth and nineteenth centuries during colonial expansion, acquiring its ideological character in the nineteenth century in Europe. Colonial and imperial power constructed racial codes that 
constituted the current racist ideology (Gilroy, 2001; Guillaumin, 1995), with colonial institutions acting as the primary context for shaping identities and the origins of the modern conception of race (Muck, 2011). Colonial societies forged identities, defining white as the universal subject. In this sense, power and identities work together to legitimize or delegitimize certain identities (Ribeiro, 2017). A debate thus begins on how to classify civilizations, emerging during the eighteenth and nineteenth centuries an ideology of race based at the same time on common sense and science to authorize and spread the bases and abuses of race, giving also passage to colonialist exploitation based on the classification, hierarchization and racial naturalization with the intention to control certain populations (A. Prasad, 2006; Guillaumin, 1995; Walton \& Caliendo, 2011).

Therefore, race was also built by capitalist forms of production. Many races were considered as animals, therefore not human, to justify their enslavement and use in the development of capitalism (Ferguson, 2003). Racializing African culture is a secular trend of the capitalist mode of production, where the notion of nation and property has as its product the exclusion of races and classes, serving as a justification for slavery (Ferguson, 2003; Walton \& Caliendo, 2011). In this sense, there has been an attempt by capitalism to overshadow the possible relations between capitalism, race and class. Thus, populations are racialized, and the production of nonwhite labor is something not accidental but constitutive of race. Racialized ethnic minorities become producers of capitalist surplus value, since superfluous populations are indispensable laborers for capital and are always ready to be exploited according to the interests of the capital (Ferguson, 2003). In contemporary times, racialization produces barriers to the work of racialized and inferior subjects. Puwar (2004) notes that while the glass ceiling in the workplace has been significantly broken in relation to gender, in relation to race there is still a concrete roof that has been scratched only superficially.

According to Acker (2006, p. 444), class "refers to the continuous and systematic difference in access and control of resources for provisioning and survival", that is, class defines the asymmetry of power and forms of control of the means of subsistence in society (Acker, 2011). The author considers as means of subsistence monetary aspects related to wages and jobs that produce manifest inequalities - for example, the hierarchical position that an individual occupies in the organization. Thus, social class is an identity present in contemporary societies usually based on social, cultural and economic aspects, constituting a factor that interferes with the opportunities and chances that an individual will have in life (Scully \& Blake-Beard, 2006). Socioeconomic conditions act in the construction of identity producing differences between individuals that act as markers of social classes (Sales, 2014) by which class divisions are based on economic processes of production and consumption (Yuval-Davis, 2006). Class studies have as their seminal point Marx's (1992) work with his critique of the dialectical relations between the proletarian and capitalist classes, emphasizing relations of class domination, as well as Weber (1978) in stating that people consider their situation as a group status. In this sense, Marx considers class as a descriptive and transformative concept, since it is constructed by the economic conditions of existence that shape the lifestyle, the interests and the formation of the subject in relation to the other classes (Spivak, 1988). In analyzing the intersections between gender, class and race, Davis (1983) demonstrates that black women and men are racially 
exploited by capitalism and oppressed by racism. Focusing her analysis on black women, Davis (1983) argues that racism and sexism converge, since wages received by white domestic women were established by setting the racist criterion used to assign black domestic wages, that is, wages of working women were established by reference to the black women.

Gonzales (1982) asserts that, in the Brazilian society, poverty and race are constructed together. She affirms that, in Brazilian history, the racial minorities were confined to the favelas, where the hygiene and health conditions are precarious and public polices are not there to protect, but to repress and frighten, benefiting the system with the maintenance of these conditions by the conservation of cheap workforce to be used. Figueiredo (2002), when analyzing black liberal professionals, shows that the rise of social class of blacks is seen as an exception to the rule, since there are structural racial barriers that hinder the social rise of blacks and mestizos in Brazilian society. In this sense, Guimarães (1998) affirms that racism manifests precisely in the structural inequalities that produce inequalities of access to education, income and work. This system of structural inequalities in Brazil is historically attributed as only a problem related to class and not to race. As Pierson (1945) demonstrates, the darkest black occupies the lowest positions of economic and social life and, therefore, suffers more social class inequalities, masking in the Brazilian context the discrimination based on racism as if it were discrimination based on social class (M. N. da Silva, 2000). In this sense, based on the belief that racism was discrimination based on social class, some authors (Fernandes, 1978) believed that once social class economic problems were solved there would be no more racial discrimination.

Racism is an ideology that establishes dependence, exploitation and appropriation of the bodies and labor of certain races, producing slaves and hired laborers, while also being the producer of these racialized bodies and jobs (Juteau-Lee, 1995). However, colonial racism does not aim solely to produce bodies and the exploitation of bodies through labor. Colonialism aims to naturalize and legitimize European superiority not just by generating asymmetries of power but also by attempting to produce the identity of the colonized "not only because of the economic and political benefits that colonialism brought but also because of colonialism's important role at the level of the Psyche" (A. Prasad, 2006, p. 130).

Brazil was the country of the Americas that received the largest contingent of African slaves and one of the countries where slavery lasted longest in the world (Klein \& Luna, 2010). In addition, Degler (1971) states that the level of miscegenation among Portuguese, blacks and local indigenous populations in Brazil is considered the largest in the world when compared to other colonies, which hindered the development of a rigid binary categorization system between whites and blacks as occurred in the United States (Muck, 2011). The process of miscegenation was even defended by Brazilian evolutionist scientists. Lacerda (1912) believed in miscegenation as a form of social regeneration of blacks, Indians and mestizos. Defenders of miscegenation believed that blacks, Indians and mestizos represented backward and inferior races, and only constant miscegenation with European whites could promote the evolution of such races (Schwarcz, 2012). 
The mixing of races in Brazil is very frequent, a mix that makes the racial borders much more pervasive and gives rise to several new racial categories. Miscegenation has made the process of racial categorization more complex, making racial identity in Brazil quite fluid (Sansone, 2004) with the establishment of several racial categories as a function of phenotypic physical characteristics, especially skin color (Sansone, 1996), such as white, mulatto, brown, light brown, dark brown, black, among others, a fact that contributed to the non-emergence of a segregationist binary policy. It is precisely because a segregationist racial model, such as in the USA, was not developed in Brazil due to this high fluidity in racial classification that the myth Brazil would be a racial democracy (Freyre, 1986) emerged and created the belief that there would be no racism in Brazil (Muck, 2011; Rosa, 2014).

However, "racism is constitutive of the production of Brazilian subjectivity, which is marked by the superiority of white people" (Silveira \& Nardi, 2014, p. 18, our translation). Being white brings social and material benefits in the Brazilian society. In addition, racism manifests through whitening, stating the superiority of being white in racist societies. Making whitening something fundamental for racialization mean seeing whitening not as a property of certain bodies but as part of the social relations by which whitening is reproduced through institutional practices and social processes (Swan, 2010). Whitening is a form of normalization that acts as the basis of the racial system by which white supremacy and superiority is stated, and the end of racism requires the end of whitening (Jensen, 2011). Moreover, in the Brazilian context, social class influences the racial classification of people. There is a whitening system related to social mobility in which phenotypically black people acquire the social status of white ascending socially (Paixão \& Carvano, 2008; Schwarcz, 2012; Wagley, 1952). Thus, social class can act as a form of whitening or blackening (Azevedo, 1995; M. N. da Silva, 2000; N. do V. Silva, 1994).

The high degree of miscegenation in Brazil contributes to the creation of the myth that there is great social mobility in the Brazilian context called by Degler (1971) as the mulatto escape hatch, because the high Brazilian racial miscegenation generated the possibility of not being white or black, but mulatto. The light brown color of the mulatto makes the skin obscure and dubious as a racial signifier, making the mulatto neither black nor white. However, despite the high degree of miscegenation and a non-segregationist policy, Brazil is not a racial democracy as described by Freyre (1986) and does not have a high rate of social mobility. Despite the nonbinary and non-segregationist racial system, many racial inequalities persist in Brazil, destroying the myth of racial democracy and social mobility (Muck, 2011).

Racial prejudice in Brazil is strongly influenced by physical (phenotypic) appearance, called by Nogueira (2007) as mark prejudice. In this logic, kinship, genealogy and ancestry are not determinants in the process of racialization, because people are classified racially because of the phenotype, e.g., skin color, nose shape and hair type. This is something very different from what occurs in the USA, where the prejudice of origin prevails, in which the racial classification of a person is genotype (one drop of blood); that is, a person can be classified as black regardless of their skin color, since the simple presence of a distant black ancestor determines his race to be black, even if this person has white skin (Nogueira, 2007; Rosa, 2014). 


\section{Method}

This article is the result of a broader qualitative research about the impact of affirmative action policies over the identity construction and the inclusion of undergraduate management students. The subjects of the research were undergraduate students of management of a Brazilian university that has racial and social policies targeting black, brown and indigenous students, as well as poor students. Before joining the university and during their stay there, questions about race and class are present in the lives of undergraduate students. There is no such policies for postgraduate studies. In addition, the Brazilian Ministry of Education requires that the curriculum of undergraduate courses in management addresses race issues.

The production of data occurred through focus group (Fern, 2001). Knoblauch and Schnettler (2012) argue that recording focus groups in video produces extremely useful and rich material for analyses using qualitative methods such as discourse analysis. Focus groups make it possible to interactively understand the processes by which intelligibilities about race are constructed. Six different focus groups occurred with a total participation of 38 students. The researcher conducted the focus groups according to a protocol. According to Godim (2003), focus groups produce data through group interactions. As a technique, it occupies an intermediate position between in-depth interviews and participant observation. According to the author, focus groups are resources that allow us to understand the processes of constructing the perceptions and attitudes of human groups. For Godim (2003), the focus group moderator occupies a position of facilitator of the discussion and the formation of opinions on a predetermined topic is taken up. In our case, the topic is focused on racial and class identities and their intersections.

In relation to race, 20 students declared themselves as being white, 8 as black, 7 as brown, 1 as mixed, 1 as Indian/yellow, and 1 student declared to be of human race. Students also declared themselves in relation to their social class, with 25 students claiming to be middle class, 10 low middle class, 2 poor, and 1 low class.

With prior authorization from all participants, the focus groups were recorded on video, totaling 514 minutes of video recording. The recording was later transcribed for the analysis of data. In order to preserve anonymity, the students were coded by the letter E followed by a number, thus varying from E1 to E38, with their self-declaration of race and class being added to the codes in parentheses. The questions asked during the focus groups were part of a semistructured interview protocol with two blocks of questions: (a) a first block exploring intelligibility and the concept of race, and (b) a second block with questions about possible intersections of race.

The data produced were analyzed using Foucault's discourse analysis. The discourse analysis developed by Foucault (2003a) is not based on methods of linguistics, or the search for hidden meanings or even grammatical analyses. In referring to Foucault's influence in his postcolonial studies, Ribeiro (2017, p. 56, our translation) states that Foucault's notion of discourse is "not to think of discourse as a piled of words or a concatenation of phrases that claim meaning in itself, but as a system that structures certain social imaginary, because we will be talking about 
power and control". For the philosopher, discourse analysis must seek to "know what conditions are imposed on any subject so that he/she can introduce himself/herself, functioning, serving as a knot in the systematic network of what surrounds us" (Foucault, 1996, pp. 30-31, our translation), establishing a historical analysis of the discourse that tries to investigate the existence of certain objects that develop, function and modify themselves without any reference to something considered as intuitive and grounded in a subject. Thus, what matters to Foucault (2003b) in discourse analysis is the role that a statement plays, that is, the economic, social and political roles, among others, of an utterance within a historical context is that should be searched and analyzed. Foucault (2003b) asserts that

"What interests me in the discourse problem is the fact that someone said something at a given time. That isn't the sense that I seek to show, but the function that can be assigned once this thing was said at that time" (p. 255).

For Foucault (2003a), when something is said, what is necessary to analyze is the role of what was said in a given time and space, trying to establish the relations of the discursive events with other economic, political, social and institutional events. For Foucault (1996), the discursive event reminds us of a way of understanding the very dynamics of life in which an entire domain is liberated. The domain becomes something immense, however definable, being constituted by the whole set of all statements, whether discursive or non-discursive. Among the various objects that function intuitively and based on a subject, this article analyzed the objects of race and class, trying to analyze the political roles of the intersections of race and class, that is, the historical functions of this discursive event in the Brazilian context and its political strategies. In this context, discourse analysis is an appropriate method for studying identities by emphasizing that identity processes are cultural, social, and collective rather than individual phenomena (Ainsworth \& Hardy, 2004). Foucault (1970) believes that, in general, discourse constitutes and is constituted by the social world. In this way, discourse may exercise several roles at the same time, such as political, economic, and social, among others. Discourse analysis is an appropriate analytical approach for the research carried out in this article precisely because it seeks to understand the meanings related to racial identities produced in management students, allowing evidence of the mediation between language and the socially constructed reality in relation to race. Thus, the intersections between race and class evidence two dimensions of analysis: (a) how the intersection between race and class resignifies race beyond phenotypical characteristics, and (b) the political goal and strategy of this process of race resignification by class.

\section{Intersectionality between Race and Class}

Identities manifest political and structural inequalities and cannot be seen in isolation (Acker, 2011; Braidotti, 1997; Harding et al., 2013; Holvino, 2010). Identities are mutually constituted in a process that is always unfinished and in constant construction and deconstruction. Therefore, race identities are affected and affect other identity expressions, such as social class, which makes race fluid and hybrid (Harding et al., 2013; Holvino, 2010). Although this article focuses only on how race is affected by social class aspects, the intersections between race and 
class should be considered as mutual and simultaneous processes of construction of both race and class (Acker, 2011; Harding et al., 2013; Holvino, 2010) in a constant game of affection and resignification (Bredström, 2006; Harding et al., 2013; Phoenix \& Pattynama, 2006; YuvalDavis, 2006).

The next subtopics of the article analyze the particularities in the intersectionality between race and class in the Brazilian society. First, it focuses on the analysis of how the meanings of race are intersected, constituted and influenced by social class, resignifying race and emphasizing how the process of identity construction of race is fluid, as well as how social class acts in racial whitening. The process by which race is resignified by social class is here called classification of race. The paper then seeks to understand the local historical justifications that underlie this process, the political strategies by which class is used to hide the action and existence of structural racism in Brazil, as well as its consequences for racial minorities in terms of labor.

\section{The classification of race}

The intersectionality of class and race demonstrates the continuous and complex entanglement of processes of difference, exclusion and inclusion (Acker, 2011). "Intersectionality is thus useful as a handy catchall phrase that aims to make visible the multiple positioning that is in everyday life and the power relations that are central to it" (Phoenix \& Pattynama, 2006, p. 187). The intersectionality of class and race affirms the continuous and complex process of intertwining identities that produce differences, exclusions, inclusions and discriminations (Acker, 2011), whereby race and class identities form an interdependent system and are experienced and constituted simultaneously and mutually constitutive, that is, united rather than separate or additive, but also produce oppression and social hierarchies (Acker, 1999, 2011; Collins, 1995). In this intersectional process by which race is resignified, it was verified that social class acts as whitening in the Brazilian context. Whitening through social class evidence how race is classified and constituted by aspects related to social class, emphasizing the processes by which race is redeemed and produced by class.

"I have a friend who studied at SCHOOL X [a private school attended by rich people] and was black, the only black man in his room right now. And he talked to his friends, to everyone, to things and things, so his friends did not consider him black. [...] He has white features, a thin nose and such, but he is black, true black [...]. They made [racist] jokes around him, but they did not consider him black." (E8, Black, Poor).

The discourse of E8 (Black, Poor) shows the importance of phenotypic traits in the definition of race in Brazil (Nogueira, 2007; Rosa, 2014). Skin color, hair type and nose shape, among other phenotypic characteristics, are crucial for the definition of race to which a subject belongs, not applying to the Brazilian context the theory of one drop of blood, demonstrating the prevalence of mark discrimination rather than origin discrimination. However, the fact that E8's friend (White, Rich) studies in a college for the rich, that is, belonging to a higher social class, coupled with some phenotypic characteristics, such as having a thin nose, makes him not to be considered black by his schoolmates, despite his black skin. A fine nose is considered an 
attribute belonging to the white race, which demonstrates the prominent level of racial miscegenation in Brazil (Degler, 1971) in the search for whitening (Lacerda, 1912; Schwarcz, 2012).

However, as E8 (Black, Poor) states, phenotypic aspects such as having black skin do not determine the race of his friend in the Brazilian context. It is not simply racial miscegenation with whites that produces whitening. The social class to which the subject belongs is an important factor for whitening and resignification of race, making racial intelligibility exceed phenotypic characteristics (Hall, 2000). Whitening in the Brazilian society is obtained not only by the miscegenation between African and European races but also by the social class to which the subject belongs. Having phenotypic traits of racial minorities but belonging to higher social classes make the individual white in Brazil. Thus, in spite of the centrality in phenotypic aspects in race intelligibility, social class has great importance in the resignification of race, and the higher the social class to which a subject belongs, the whiter he/she becomes (Paixão \& Carvano, 2008; M. N. da Silva, 2000; N. do V. Silva, 1994; Wagley, 1952).

"For example: like this, the brown person, if you were to talk he/she is brown and finished. But you see his/her class! Who is the father? The father is a rich businessman that owns a company, so we'll ask: you consider the guy like what? I would consider him as white because of his/her class." (E10, Black, Middle).

The affirmation of E10 (Black, Middle) clarifies social class performance as a form of whitening (Azevedo, 1966; M. N. da Silva, 2000; N. do V. Silva, 1994), demonstrating the specificities of intersectionality between race and class in Brazil. Poverty as a form of blacking can be evidenced in the discourse of E24 (White, Middle): "He is in a more unfavorable social condition. What makes him black is exactly this to be seen as inferior" (E24, White, Middle). In this sense, social class is fundamental to the process of Brazilian racialization, demonstrating that both whitening and blackening are not a phenotypic property of the bodies themselves (DuBois, 1970).

For E24 (White, Middle), what makes someone black is belonging to lower social classes, which demonstrates that the process of Brazilian racialization is the result of highly complex relationships, social processes and institutional practices (Baines, 2010; Sansone, 1996; Swan, 2010). Racism is an ideology (Guillaumin, 1995; Juteau-Lee, 1995) and social mobility for higher social classes produces ideological whiteness, while social mobility for lower classes produces an ideological blacking by which phenotypic aspects are no longer considered determinants in the definition of race, making people of lower classes be considered racial minorities, whereas people of the upper classes are considered white (Paixão \& Carvano, 2008; Schwarcz, 2012; Wagley, 1952).

"I believe that social class is what differentiates a black person from a white person. I think it is the class. There are people who say that the lower class and different class belongs to black people, the other class is only white, when he/she is black he/she is only the poorest [...]. I think that what when we say social class we are talking about the origin of the person, culture, the way that the family raises you, everything that differentiates." (E26, Black, Lower Class). 
E26 (Black, Lower Class) attributes great importance to social class in the production of social differences, disregarding racial aspects in the production of these differences, denying the existence of structural racism. In spite of social ascension of racial minorities, one's race does not mean that the individual will be completely free of Brazil's structural racism (Azevedo, 1995; Figueiredo, 1999; Pinho, 2008; M. N. da Silva, 2000). It simply means that social class can attenuate individual racist acts and practices or individual racism (Henry \& Tator, 2005; Pierce, 2014), producing a new sense of race that is beyond skin color but does not eliminate the presence of structural racism (Pierce, 2014) at the macrosocial level.

The great importance of social class in the production of social differences is a strategy of denying and neglecting structural racism (Guimarães, 1998; M. N. da Silva, 2000; Silveira \& Nardi, 2014) by considering the inequalities produced by race as something determined by the social class and not race. However, in an indirect way, whitening by social class shows the existence of structural racism in Brazil. Whitening through social class demonstrates the existence of structural racism, even when operating through class, because the white race remains the goal and the standard to be followed, acting as a form of normalization of racial minorities that is premised on superiority and white supremacy (A. Prasad, 2006; Jensen, 2011).

In this way, categories and social positions are relational, and intersectionality makes visible the interweaving between the multiple social positions and the relations of power that constitute the racialized subject (Phoenix \& Pattynama, 2006), highlighting the multiple disadvantages experienced by individuals positioned inferiorly at the intersections of different markers and categories of differences. However, the identity of the subject cannot be considered to be simply the sum of these several markers (Bredström, 2006; Harding et al., 2013; Phoenix \& Pattynama, 2006; Yuval-Davis, 2006). The boundaries between race and class identities are so fluid in the Brazilian context that one cannot be said to exist apart from the other, stating how race is mutually constituted by class, a process here called classification of race, to the point where the boundaries between these identities become quite fluid (Linstead \& Pullen, 2006; Lovaas \& Jenkins, 2007; Seidman, 1994; Tracy \& Scott, 2006), as will be shown in the following section.

Therefore, after analyzing how the meanings of race are constituted and redefined by social class, it is now necessary to analyze the political strategies of this process, the historical discursive aspects that contributed to the classification of race in the Brazilian context.

\section{The political strategies of classification of race and its historical justifications: the myth of racial democracy}

First, this paper will analyze the political strategies that make race a social class aspect. Next, the historical justifications that explain the classification of race in the Brazilian context and its social consequences in labor will be presented. The intersectionality between race and class is so expressive in Brazilian society that students find it difficult to differentiate race from class. The boundaries between race and class are opaque and nebulous (Linstead \& Pullen, 2006; Lovaas \& Jenkins, 2007; Seidman, 1994; Tracy \& Scott, 2006) in the Brazilian society, constituting a 
grey area, to the point that E34 (White, Low Middle) stated "I always confound class with race!".

In strategic political terms (Letiche, 2009), two interrelated factors contribute to the constitution of this grey area: (a) the myth of racial democracy, and (b) the denial of structural racism. The resignification of race from class aspects makes race not considered as a marker that produces inequalities and social differences. The belief in racial democracy makes racial aspects seen as irrelevant in the production of inequalities (Guimarães, 1998; M. N. da Silva, 2000; Silveira \& Nardi, 2014), contributing to people's tendency to categorize racial inequalities as being only class inequalities, contributing to a belief in racial democracy that is based on the fact that there is no racism in Brazil, but only inequalities in the function of social class to which an individual belongs. The denial of the existence of structural racism causes racist practices to be attributed to and seen as an individual act present only at the micro-social level, rather than a structural component (Pierce, 2014), thereby serving the denial of the presence of structural racism in Brazilian society (M. N. da Silva, 2000). In turn, the denial of the existence of structural racism and the attribution of racist practices as an individual act reinforce the belief that Brazil is a racial democracy, despite the deep racial inequalities present in Brazilian society (Figueiredo, 1999, 2002).

Since racism is a system that produces inequalities of opportunities evidenced in access to income, education, work, health and housing, all aspects related to social class, it is common for people in Brazil to understand racial inequalities as only a matter of class (Guimarães, 1998), strengthening the idea of the existence of racial democracy, in which Brazilian social inequalities are not the result of racial issues. The denial of the existence of structural racism in Brazilian society occurs through the intelligibility of racial issues as being only aspects of class and not of race, a fact evidenced in the discourse below E27 (White, Lower Middle).

"You may be white, black or Indian, but if you are poor you will be treated with a certain difference at a certain location. In a job interview, they ask things, then you go to put away, you will be separated. It is not so much the race there, but the class." (E27, White, Low Middle).

In the Brazilian social context, most people believe that the racial inequalities present in everyday life in society are aspects only of social class (Guimarães, 1998; M. N. da Silva, 2000) and that once class inequalities have been overcome racial inequalities will automatically disappear, reinforcing the myth that Brazil is a racial democracy and that there is no structural racism. In this logic, black, brown and indigenous persons become responsible for their inferior social class, and only through their individual effort can they escape this situation of economic inequality. Thus, one of the main characteristics of Brazilian racialization (Gilroy, 2001; Omi \& Winant, 1986; Yuval-Davis, 2006) is to deny that social inequalities between whites and blacks are in fact racial structural inequalities (Schwarcz, 2001; Silveira \& Nardi, 2014).

This Brazilian social context creates difficulties for people to differentiate race-based discrimination from class-based discrimination (M. N. da Silva, 2000). Thus, the intersectionality between race and class is so strong that there are practically no boundaries between these two identities in the Brazilian context; that is, the existence of extremely fluid 
boundaries declares and affirms how intensive the intersectionality between race and class is to the point of racial inequalities being considered only class inequalities. However, what are the historical justifications that explain this process? What are its social consequences to labor?

Racism is the process by which races are produced and create distinctions that impose social and economic power between racial groups justified through class categories (Walton \& Caliendo, 2011). These multiple forms of oppression by which subjects are included, excluded, and regulated (Ferguson, 2003) act intersectively. In terms of historical justifications, the fact that in Brazil most poor people are black and brown links class to racial minorities (Acker, 2006, 2011), as stated by E14 (White, Middle): "Most of the poor people living in the favelas are black." The belief that favela is a place for blacks declares that blacks belong only to lower social classes; that is, being poor makes the subject black. As E5 (White, Middle) states below, this is a historical issue.

"We have a historical problem that the white class has a higher economic power proportional to the black class. And we must break this culture of classify people, whether we are in the family unit or at school. We see very weak public policies that combat our vision that sees a certain race must stay in a particular class. You must break that down. We need public policies in education, health, work, that reduces this inequality to change the mind of many people." (E5, White, Middle).

The discourse of E5 (White, Middle) again shows the classification of race, going so far as to use the expression black class and white class instead of black race and white race, stating that race is determined by social class. E5 (White, Middle) classifies race by declaring that in Brazilian society, black people are historically poor. This has occurred because the end of Brazilian slavery occurred without any policy implementation that would guarantee black slaves access to social and economic opportunities. They had only their own bodies for food, housing, work and clothing. This process by which class constitutes race operates by establishing an essence and a truth about the black race (A. Prasad, 2012) in Brazilian racial truth games, an essence that is naturalized in daily practices and establishes a discursive intelligibility about which labor activity is adequate for certain races (Linstead \& Pullen, 2006) within a discursive formation in a given time and space (Hall, 1996).

It is because of this essence established by the discursive intelligibility produced in the truth games that E18 (Brown, Low Middle) states that "For me, society has imposed this essence. Gives coalition between job function, color and social class. [...] Because even in crime there is this difference of class. Black robs, buys drugs and sells to the rich who lives in a good neighborhood." This essential conception of identity aims precisely to maintain the established racial order, keeping intact privileged identities at the expense of identities produced as minorities (A. Prasad, 2012). On this, E7 (White, Low Middle) adds the following:

"The favela was a place that blacks occupied because they did not have their space. Like, he was piling up a lot of house and palafita and forming a community there. And that community was occupied by blacks, because at that time had that discrimination, then, everything is connected, understood?" (E7, White, Low Middle). 
As already explained, this intersection between race and class is a historically constructed imposition (Gonzales, 1982). Hence, Hall (1996) states that any form of representation is possible only because enunciation is always produced within codes that have a history, a position within the discursive formations of a particular space and time. Identities are discursive practices by which subjects position themselves as a function of others in a given time and space (Hall, 2000; Linstead \& Pullen, 2006), demonstrating the formative character of discourse (Hall, 1996). E7 (White, Low Middle) corroborates the understanding of this historical and discursive identity construction when affirming the following:

"I think once again it is a chronic problem and a historical issue. The blacks came from slaves, did not have the opportunity, from the past they did not have the opportunity to qualify, to have a better job and this reflects several things. [...] I do not think, like that, that the black man is demeaning. [...] It is a historical condition! He has always been seen like this! The person ends up naturalizing it and reproducing it often knows!" (E7, White, Low Middle).

The naturalization enunciated by E7 (White, Low Middle) is not of the order of nature or inevitable, but a discursive historical partner production by which political interests of certain groups prevail to the detriment of others (A. Prasad, 2012). These political interests are camouflaged under the veil of nature so that they cannot be questioned and problematized (Ainsworth \& Hardy, 2004). It is the continuous repetition of this discursive historical norm that creates a normalizing principle by which members of racial minorities are considered members of lower social classes. Next, E26 (Black, Lower Class) demonstrates how this norm naturalizes blacks as being poor, homogenizing and essentializing all black people (Yuval-Davis, 2006).

"Unfortunately, when you speak about poor class the first thing you think is what? A black person. When you say that a person is rich middle class, unfortunately the first thing that comes in your head is a white person. [...] We are hammered like this - black people are poor." (E26, Black, Lower Class).

Thus, race meaning social class must be understood as a discursive historical production that has been hammered in our minds. Slavery and European colonization have produced racial codes that shape identities and the conception of race in the Brazilian context at the psyche level (A. Prasad, 2006; Gilroy, 2001; Guillaumin, 1995; Muck, 2011). The social consequence of this is that colonial racialization has established the exploitation and appropriation of particular bodies by labor, racializing these bodies through slave labor (Juteau-Lee, 1995), constituting class-specific identities by racialized labor (Hall, 1993). Thus, racialization is the "process by which social, economic, and political forces determine the content and importance of racial categories, and by which they are in turn shaped by racial meanings" (Omi \& Winant, 1986, p. 61), as E36 (White, Middle) discusses explicitly:

"I think the main relationship between these points is the historical factor. For example, why is it that the black man today is likely to be poor? Since the ancestors they have had less opportunity, have had low education, which is passing generation and generation, and today it is more difficult for 
them to attempt a socio-economic social rise because of these historical factors." (E36, White, Middle).

In this way, the process by which race is classified becomes a relevant political device for maintaining the labor exploitation of certain groups in a capitalist context of production (Ferguson, 2003; Walton \& Caliendo, 2011). The result of this historical process is that, despite the end of slavery in Brazil, colonial racialization has produced racial capitalist value up to the present day, at the same time constructing barriers and walls in relation to labor position based on race. In this sense, the fact that racial minorities belong to lower social classes is a selffulfilling historical prophecy, since the fact that a certain person belongs to a lower social class makes him racially recognized as a minority and vice versa.

Considering that social class is related to the type of work activity that the subject exercises, the fact of belonging to a racial minority in Brazil causes the subject to be associated and considered as being more appropriate to perform work of lower social status and lower pay: "A Negro is poor, and he is a general service assistant! If you're going to use that race, work, and poverty, that's it. Black, he is poor, he is a street-sweeper, a general service assistant, he is a mason!" (E23, Black, Low Middle). This statement demonstrates how racialized work is in Brazil (Hall, 1993): "There is a very close relationship between [race and] work, right? [...] there is a very close relationship between class, race and these works [lower works]" (E24, White, Middle). This statement demonstrates how these identities are political categories that create hierarchies (Acker, 1999, 2011; Collins, 1995; Gilroy, 2001) and establish power relations (Jones \& Stablein, 2006).

Not only blacks and browns but also indigenous populations are seen as unsuitable for jobs with higher social status and better remuneration. This fact demonstrates how the process of racialization hinders and limits the access of racial minorities to the best labor opportunities, as the following discourse shows: "The Indian, for example, when you see an Indian you already deduce that he is class D, Class E in financial terms" (E30, White, Middle). The difficulty of racial minorities accessing employment and social opportunities ends up condemning them to lower social classes, making social mobility difficult. Hence, inequalities of race and class are intersectional and act as systems of oppression that constitute each other (Bredström, 2006). However, despite the classification of race, these two different forms of identity, race and class, cannot be seen as similar and equally structured (Phoenix \& Pattynama, 2006; Verloo, 2006; Yuval-Davis, 2006).

\section{Conclusion}

First, the article highlighted that the intersections between race and class resignify race beyond phenotypical characteristics, showing that class acts in modifying the meaning of race, white or black race. In this sense, the social class is an important characteristic for the whitening and resignification of race in Brazilian society. Second, it analyzes the strategic political goal of this process of classification of race as the denial of the existence of structural racism masked by the belief in the myth of racial democracy. In this sense, the resignification of race by class makes 
race not to be considered a social marker that produces inequalities and social differences, causing racial identities to be considered irrelevant in the production of social inequalities, contributing to management students' tendency to categorize racial inequalities as being only class inequalities. The classification of race is a political strategy that goals hide the importance of racial identities as a social marker.

Race cannot be understood in isolation; rather, it must be understood considering its intersections and the social-historical context in which it is produced. It can be concluded that in the Brazilian context, class acts to resignify race beyond the phenotypic characteristics that underlie race prejudice, acting as a form of whitening or blackening of the subjects. The boundaries between race and class identities are so fluid that they constitute a grey area, causing racial aspects to be considered as class aspects by management students. This causes race not to be considered as a social marker that produces inequalities, relegating racial inequalities as mere class issues in a strategy of denying the existence of structural racism in Brazil, collaborating with the reproduction of the myth that Brazilian society is a racial democracy. The reduction of race to social class is a process of masking the race as a social marker, delegitimizing race as a social marker that produces inequalities, making it invisible. In this sense, Ribeiro (2017) affirms that invisibility kills, being necessary a resignification of the black identity in the Brazilian social context in order to produce the visibility of race as a social marker that produces differences.

Considering that management students will be in the future leaders that will develop diversity policies in private and public organizations, the deconstruction of the meaning by which the conception of racial identity is merely an expression of class is necessary and need to be approached in the content of business courses. Without such deconstruction, race will not be considered a social marker that produces inequalities in the workplace, thus the existing inequalities in organizations produced by racial aspects will not be considered in diversity policies, remaining race identities invisible, non-existent, and irrelevant to the organizational leaders. This silence will perpetuate the fact that race is not considered an organizational phenomenon and an organizing principle (P. Prasad et al., 2006), even though organizations also act in the processes of racialization and social classification (Kalonaityte, 2010). The myth of racial democracy contributes to the fact that privileges and inequalities produced by structural racism are neither considered nor problematized by management students and Brazilian society as a whole, perpetuating privileges and inequalities in workplace. Structural racism is concealed and legitimated when embedded in class processes, making the racial privileges of the privileged are not considered a privilege (Acker, 2006). Therefore, racial issues should be addressed and discussed with management students during their college education, aiming to problematize and break with hegemonic intelligibility about race and its strategy in maintaining the privileges of races considered non-minority.

To break with racism, it is necessary not only to liberate white supremacy but also to break with the processes of racialization and racialized thinking (Gilroy, 2001). This article analyzed how race is intersected by class in the Brazilian context. However, the intersectional processes are mutual and do not occur only in one direction. In this sense, not only is race resignified and 
constituted by class, but class is also racialized and constituted by race. Thus, the processes by which class is racialized deserve attention and must be analyzed by organizational scholars in future research. Beyond that, the way in which organizations act in the processes of racialization has not yet been explored and need to be.

\section{References}

Acker, J. (1999). Rewriting class, race, and gender: Problems in feminist rethinking. In M. M. Ferree, J. Lorber, \& B. B. Hess (Eds.), Revisioning gender (pp. 44-69). Thousand Oaks, CA: Sage.

Acker, J. (2006). Inequality regimes gender, class, and race in organizations. Gender $\mathcal{E}$ Society, 20(4), 441-464. https://doi.org/10.1177/0891243206289499

Acker, J. (2011). Theorizing gender, race and class in organizations. In E. Jeanes, D. Knights, \& P. Y. Martin (Eds.), Handbook of gender, work and organization (1st ed., pp. 65-80). West Sussex, UK: Wiley-Blackwell.

Ainsworth, S., \& Hardy, C. (2004). Discourse and identities. In D. Grant, C. Hardy, C. Oswick, \& L. Putnam (Eds), The Sage handbook of organizational discourse (pp. 153-173). London, UK: Sage.

Alcoff, L. (1991). The problem of speaking for others. Cultural Critique, 20, 5-32. https://doi.org/10.2307/1354221

Anzaldúa, G. (1987). Borderlands/la frontera: The new mestiza. San Francisco, CA: Aunt Lute Books.

Appiah, A. (1985). The uncompleted argument: DuBois and the illusion of race. Critical Inquiry, 12(1), 21-37. https://doi.org/10.1086/448319

Azevedo, T. (1966). Cultura e situação racial no Brasil. Rio de Janeiro, Brazil: Civilização Brasileira.

Azevedo, T. (1995). As elites de cor: Um estudo de ascensão social. São Paulo, Brazil: Ed. Nacional.

Baines, D. (2010). Gender mainstreaming in a development project: Intersectionality in a post-colonial un-doing? Gender, Work and Organization, 17(2), 119-149. https://doi.org/10.1111/j.1468-0432.2009.00454.x

Barnard, I. (1999). Queer race. Social Semiotics, 9(2), 199-212. https://doi.org/10.1080/10350339909360432

Bhabha, H. (1994). The location of culture. London, UK: Routledge.

Braidotti, R. (1997). Comment on Felski's "The doxa of difference": Working through sexual difference. Signs: Journal of Women in Culture and Society, 23(1), 23-40. https://doi.org/10.1086/495232

Bredström, A. (2006). Intersectionality: A challenge for feminist HIV/AIDS research? European Journal of Women's Studies, 13(3), 229-243. https://doi.org/10.1177/1350506806065754

Butler, J. (1990). Gender trouble: Feminism and the subversion of identity. New York, NY: Routledge.

Butler, J. (1993). Critically queer. GLQ: A Journal of Lesbian and Gay Studies, 1(1), 17-32. https://doi.org/10.1215/10642684-1-1-17

Butler, J. (1997). The psychic life of power: Theories in subjection. Stanford, CA: Stanford University Press.

Calás, M. B., \& Smircich, L. (1996). Thematic editorial on gender, race, class and organization. Organization, 3(4), 459-460. https://doi.org/10.1177/135050849634001

Cohen, C. J. (1997). Punks, bulldaggers, and welfare queens: The radical potential of queer politics? GLQ: A Journal of Lesbian and Gay Studies, 3(4), 437-465. https://doi.org/10.1215/10642684-3-4-437

Collins, P. H. (1995). Symposium: On West and Fenstermaker's "doing difference". Gender $\mathcal{B} ~ S o c i e t y, 9(4), 491$ 494. https://doi.org/10.1177\%2F089124395009004006

Cox, T., \& Nkomo, S. (1990). Invisible men and women: A status report on race as a variable in organization behavior research. Journal of Organizational Behavior, 11(6), 419-431. https://doi.org/10.1002/job.4030110604

Crenshaw, K. (1989). Demarginalizing the intersection of race and sex: A black feminist critique of antidiscrimination doctrine, feminist theory, and antiracist politics. The University of Chicago Legal Forum, 1989(1),

139-167.

Retrieved

from 
http://chicagounbound.uchicago.edu/uclf/vol1989/iss1/8?utm_source=chicagounbound.uchicago.edu\%2Fuc lf\%2Fvol1989\%2Fiss1\%2F8\&utm_medium=PDF\&utm_campaign=PDFCoverPages

Davis, A. Y. (1983). Women, race $\mathcal{E}$ class. New York, NY: Vintage Books.

Degler, C. (1971). Neither black nor white: Slavery and race relations in Brazil and the United States. New York, NY: Macmillan.

DuBois, W. E. B. (1970). The conservation of races. In P. S. Foner (Ed.), W. E. B. Du Bois speaks: Speeches and addresses 1890-1919 (pp. 83-95). New York, NY: Pathfinder.

Ely, R. J., \& Meyerson, D. E. (2000). Advancing gender equity in organizations: The challenge and importance of maintaining a gender narrative. Organization, 7(4), 589-608. https://doi.org/10.1177/135050840074005

Ferguson, R. A. (2003). Aberrations in black: Toward a queer of color critique. Minneapolis, MN: University of Minnesota.

Fernandes, F. (1978). A integração do negro na sociedade de classes. São Paulo, Brazil: Ática.

Fern, E. F. (2001). Advanced focus group research. London, UK: Sage.

Figueiredo, A. (1999). Velhas e novas "elites negras”. In M. C. Maio \& G. Villas Bôas (Orgs.), Ideais de modernidade e sociologia no Brasil: Ensaios sobre Luiz Aguiar Costa Pinto (pp. 109-124). Porto Alegre, Brazil: Universidade Federal do Rio Grande do Sul.

Figueiredo, A. (2002). Novas elites de cor: Estudos sobre os profissionais liberais de Salvador. São Paulo, Brazil: Annablume.

Foucault, M. (1970). L'ordre du discours. Leçon inaugurale au Collège de France prononcèe le 2 décembre 1970. Paris, France: Éditions Gallimard.

Foucault, M. (1982). The subject and power. Critical Inquiry, 8(4), 777-795. https://doi.org/10.1086/448181

Foucault, M. (1996). Entrevista com Michel Foucault, por Sérgio P. Rouanet e J. G. Merquior. In M. Foucault, S. P. Rouanet, J. G. Merquior, D. Lecourt, \& C. H. Escobar (Orgs.), O homem e o discurso: A arqueologia de Michel Foucault (pp. 17-42). Rio de Janeiro, Brazil: Edições Tempo Brasileiro.

Foucault, M. (2003a). A ordem do discurso. São Paulo, Brazil: Edições Loyola.

Foucault, M. (2003b). Diálogo sobre o poder. In M. Foucault (Ed.), Estratégia, poder-saber (pp. 253-266). Rio de Janeiro, Brazil: Forense Universitária.

Freyre, G. (1986). The masters and the slaves: A study in the development of Brazilian civilization. California: University of California.

Gilroy, P. (2001). Against race: Imagining political culture beyond the color line. Boston, MA: Harvard University.

Godim, S. M. G. (2003). Grupos focais como técnica de investigação qualitativa: Desafios metodológicos. Paidéia, 12(24), 149-161. https://doi.org/10.1590/s0103-863x2002000300004

Gonzales, L. (1982). O movimento negro na última década. In L. Gonzales \& C. Hasenbalg (Eds.), Lugar de negro (pp. 9-66). Rio de Janeiro, Brazil: Editora Marco Zero.

Guillaumin, C. (1995). The specific characteristics of racist ideology (1972). In R. Miles (Ed.), Racism, sexism, power, and ideology: Colete Guillaumin (pp. 29-60). London, UK: Routledge.

Guimarães, A. S. (1998). Preconceito e discriminação: Queixas e ofensas no tratamento desigual dos negros no Brasil. Salvador, Brazil: Novos Toques.

Hall, S. (1990). Cultural identity and diaspora: Identity: Community, culture, difference. London, UK: Lawrence \& Wishart

Hall, S. (1993). Encoding, decoding. In S. During (Ed.), The cultural studies reader (pp. 507-517). London, UK: Routledge.

Hall, S. (1996). "New ethnicities". In S. Hall, D. Morley, \& K.-H. Chen (Eds.), Stuart Hall: Critical dialogues in cultural studies (pp. 441-449). London, UK: Routledge.

Hall, S. (2000). "Who needs 'identity?” In P. Du Gay, J. Evans, \& P. Redman (Eds.), Identity: A reader (pp. 15-30). London, UK: Sage. 
Harding, N., Ford, J., \& Fotaki, M. (2013). Is the 'F'-word still dirty? A past, present and future of/for feminist and gender studies in organization. Organization, 20(1), 51-65. https://doi.org/10.1177/1350508412460993

Henry, F., \& Tator, C. (2005). The colour of democracy: Racism in Canadian Society. Toronto, Canada: Thomson Nelson.

Holvino, E. (1994). Women of color in organizations: Revising our models of gender at work. In E. Y. Cross, J. H. Katz, F. A. Miller, \& E. W. Seashore (Eds.), The promise of diversity (pp. 52-59). Burr Ridge, IL: Irwin Professional Publishing.

Holvino, E. (1996). Reading organization development from the margins: Outsider within. Organization, 3(4), 520 533. https://doi.org/10.1177/135050849634009

Holvino, E. (2010). Intersections: The simultaneity of race, gender and class in organization studies. Gender, Work and Organization, 17(3), 248-277. https://doi.org/10.1111/j.1468-0432.2008.00400.x

Jensen, R. (2011). Whiteness. In S. M. Caliendo \& C. D. Mcllwain (Eds.), The Routledge companion to race and ethnicity (pp. 21-28). London, UK: Routledge.

Jones, D., \& Stablein, R. (2006). Diversity as resistance and recuperation: Critical theory, post-structuralist perspectives and workplace diversity. In A. M. Konrad, P. Prasad, \& J. K. Pringle (Eds.), Handbook of workplace diversity (pp. 145-166). London, UK: Sage.

Juteau-Lee, D. (1995). Introduction: (Re)constructing the categories of "race" and "sex": The work of a precursor. In R. Miles (Ed.), Racism, sexism, power, and ideology: Colete Guillaumin (pp. 1-28). London, UK: Routledge.

Kalonaityte, V. (2010). The case of vanishing borders: Theorizing diversity management as internal border control. Organization, 17(1), 31-52. https://doi.org/10.1177/1350508409350238

Klein, H. S., \& Luna, F. V. (2010). Slavery in Brazil. Cambridge: Cambridge University.

Knoblauch, H., \& Schnettler, B. (2012). Videography: Analysing video data as a 'focused' ethnographic and hermeneutical exercise. Qualitative Research, 12(3), 334-356. https://doi.org/10.1177/1468794111436147

Konrad, A. M. (2003). Special issue introduction: Defining the domain of workplace diversity scholarship. Group $\mathcal{E}$ Organization Management, 28(1), 4-17. https://doi.org/10.1177/1059601102250013

Lacerda, J. B. (1912). O Congresso universal das raças reunido em Londres. Rio de Janeiro, Brazil: Papelaria Macedo.

Letiche, H. (2009). Doubling: There's an escape from commodification ...? Society and Business Review, 4(1), 8-25. https://doi.org/10.1108/17465680910932432

Linstead, S., \& Pullen, A. (2006). Gender as multiplicity: Desire, displacement, difference and dispersion. Human Relations, 59(9), 1287-1310. https://doi.org/10.1177/0018726706069772

Lovaas, K. E., \& Jenkins, M. M. (2007). Introduction: Setting the stage. In K. E. Lovaas \& M. M. Jenkins (Eds.), Sexualities and communication in everyday life: A reader (pp. 1-18). Thousand Oaks, CA: Sage.

Manning, J. (2018). Becoming a decolonial feminist ethnographer: Addressing the complexities of positionality and representation. Management Leaming, 49(3), 311-326. https://doi.org/10.1177/1350507617745275

Marjo, S., Juusola, K., \& Kivijärvi, M. (2019). 'World-class' fantasies: A neocolonial analysis of international branch campuses. Organization, 26(1), 75-97. https://doi.org/10.1177/1350508418775836

Marx, K. (1992). Capital: Critique of political economy. Harmondsworth, UK: Penguin Books.

Moore, H. L. (1994). A passion for difference: Essays in anthropology and gender. Bloomington, IN: Indiana University.

Muck, W. (2011). Colonialism/postcolonialism. In S. M. Caliendo \& C. D. Mcllwain (Eds.), The Routledge companion to race and ethnicity (pp. 29-37). London, UK: Routledge.

Munro, A. (2001). A feminist trade union agenda? The continued significance of class, gender and race. Gender, Work Ë Organization, 8(4), 454-471. https://doi.org/10.1111/1468-0432.00141

Murji, K., \& Solomos, J. (2005). Racialization: Studies in theory and practice. Oxford, UK: Oxford University.

Nogueira, O. (2007). Preconceito racial de marca e preconceito racial de origem: Sugestão de um quadro de referência para a interpretação do material sobre relações raciais no Brasil. Tempo Social, 19(1), 287-308. https://doi.org/10.1590/s0103-20702007000100015 
Omi, M., \& Winant, H. (1986). Racial formation in the United States: From the 1960s to the 1980s. New York, NY: Routledge.

Oxford Committee for Famine Relief. (2017, September). A distância que nos une: um retrato das desigualdades brasileiras. Retrieved

from https://www.oxfam.org.br/sites/default/files/publicacoes/relatorio_a_distancia_que_nos_une.pdf

Paixão, M., \& Carvano, L. M. (2008). Censo e demografia: A variável cor ou raça nos interiores dos sistemas censitários brasileiros. In A. Pinho \& L. Sansone (Orgs.), Raça: Novas perspectivas antropológicas (pp. 25-62). Salvador, Brazil: EDUFBA.

Phoenix, A., \& Pattynama, P. (2006). Intersectionality. European Journal of Women's Studies, 13(3), 187-92. https://doi.org/10.1177/1350506806065751

Pierce, A. J. (2014). Structural racism, institutional agency, and disrespect. Retrieved from https://digitalcommons.sacredheart.edu/rel_fac/89

Pierson, D. (1945). Brancos e pretos na Bahia: Um estudo de contato racial. São Paulo, Brazil: Ed. Nacional.

Pinho, O. A. (2008). A antropologia no espelho da raça. In O. A. Pinho \& L. Sansone (Orgs.), Raça: novas perspectivas antropológicas (pp. 9-24). Salvador, Brazil: EDUFBA.

Prasad, A. (2006). The jewel in the crown: Postcolonial theory and workplace diversity. In A. M. Konrad, P. Prasad, \& J. K. Pringle (Eds.), Handbook of workplace diversity (pp. 121-144). London, UK: Sage.

Prasad, A. (2012). Beyond analytical dichotomies. Human Relations, 65(5), 567-595. https://doi.org/10.1177/0018726711432183

Prasad, P., Pringle, J. K., \& Konrad, A. M. (2006). Examining the contours of workplace diversity: Concepts, contexts and challenges. In A. Konrad, P. Prasad, \& J. Pringle (Eds.), Handbook of workplace diversity (pp. 1-22). London, UK: Sage.

Puwar, N. (2004). Space invaders: Race, gender and bodies out of place. Oxford: Berg.

Ribeiro, D. (2017). O que é lugar de fala? Belo Horizonte, Brazil: Editora Letramento.

Rosa, A. R. (2014). Relações raciais e estudos organizacionais no Brasil. Revista de Administração Contemporânea, 18(3), 240-260. https://doi.org/10.1590/1982-7849rac20141085

Sales, M. S. (2014). O processo de constituição da identidade na adolescência: Trabalho, classe e gênero. Psicologia EO Sociedade, 26(spe), 161-171. https://doi.org/10.1590/s0102-71822014000500017

Sansone, L. (1996). Nem somente preto ou negro: O sistema de classificação racial no Brasil que muda. Afro-Ásia, 18, 165-187. http://dx.doi.org/10.9771/1981-1411aa.v0i18.20904

Sansone, L. (2004). 'Raça', etnicidade e saúde reprodutiva: O caso afro-latino-americano. In S. Monteiro \& L. Sansone (Orgs.), Etnicidade na América Latina: Um debate sobre raça, saúde e direitos reprodutivos (pp. 57-96). Rio de Janeiro, Brazil: Fiocruz.

Schwarcz, L. M. (2001). Racismo no Brasil. São Paulo, Brazil: Publifolha.

Schwarcz, L. M. (2012). Nem preto nem branco, muito pelo contrário: Cor e raça na sociabilidade brasileira. São Paulo, Brazil: Claro Enigma.

Scully, M. A., \& Blake-Beard, S. (2006). Locating class in organizational diversity work: Class as structure, style and process. In A. M. Konrad, P. Prasad, \& J. K. Pringle (Eds.), Handbook of workplace diversity (pp. 431-454). London, UK: Sage.

Seidman, S. (1994). Symposium: Queer theory/sociology: a dialogue. Sociological Theory, 12(2), 166-177.

Silva, M. N. da. (2000). O negro no Brasil: Um problema de raça ou de classe?. Revista Mediações, 5(2), 99-124. https://doi.org/10.5433/2176-6665.2000v5n2p99

Silva, N. do V. (1994). Uma nota sobre "raça social” no Brasil. Estudos Afro-Asiáticos, 26, 67-80.

Silveira, R. da S., \& Nardi, H. C. (2014). Interseccionalidade gênero, raça e etnia e a lei Maria da Penha. Psicologia Eु Sociedade, 26, 14-24. https://doi.org/10.1590/s0102-71822014000500003 
Spivak, G. C. (1988). Can the subaltern speak? In C. Nelson \& L. Grossberg (Eds.), Marxism and the interpretation of culture (pp. 271-313). Urbana, IL: University of Illinois.

Swan, E. (2010). "A testing time, full of potential?": Gender in management, histories and futures. Gender in Management: An International Journal, 25(8), 661-675. https://doi.org/10.1108/17542411011092327

Tate, S. A. (2005). Black skins, black masks: Hybridity, dialogism, performativity. Aldershot, UK: Ashgate.

Tracy, S. J., \& Scott, C. (2006). Sexuality, masculinity, and taint management among firefighters and correctional officers: Getting down and dirty with 'America's heroes' and the 'scum of law enforcement'. Management Communication Quarterly, 20(1), 6-38. https://doi.org/10.1177/0893318906287898

Valentine, G. (2007). Theorizing and researching intersectionality: A challenge for feminist geography. The Professional Geographer, 59(1), 10-21. https://doi.org/10.1111/j.1467-9272.2007.00587.x

Verloo, M. (2006). Multiple inequalities, intersectioinality and the European Union. European Journal of Women's Studies, 13(3), 211-228. https://doi.org/10.1177/1350506806065753

Wagley, C. (1952). Race and class in rural Brazil. Paris, France: UNESCO.

Walton, F. C., \& Caliendo, S. M. (2011). Origins of the concept of race. In S. M. Caliendo \& C. D. Mcllwain (Eds.), The Routledge companion to race and ethnicity (pp. 3-11). London, UK: Routledge.

Weber, M. (1978). Economy and society. Berkeley, CA: University of California.

Yuval-Davis, N. (2006). Intersectionality and feminist politics. European Journal of Women's Studies, 13(3), 193-209. https://doi.org/10.1177/1350506806065752

Zanoni, P., Janssens, M., Benschop, Y., \& Nkomo, S. (2010). Unpacking diversity, grasping inequality: rethinking difference through critical perspectives. Organization, 17(1), 9-29. https://doi.org/10.1177/1350508409350344

\section{Author}

\section{Eloisio Moulin de Souza}

Universidade Federal do Espírito Santo, Centro de Ciências Jurídicas e Econômicas

Av. Fernando Ferrari, 514, Goiabeiras, 29075-910, Vitória, ES, Brazil

eloisiomoulin@gmail.com

(iD) http://orcid.org/0000-0002-0775-7757 